\title{
Mantle cell lymphoma with partial involvement of the mantle zone: an early infiltration pattern of mantle cell lymphoma?
}

\author{
Assia Bassarova • Anne Tierens • \\ Grete Fossum Lauritzsen • Alexander Fosså • \\ Jan Delabie
}

Received: 6 December 2007 /Revised: 14 April 2008 / Accepted: 16 April 2008 / Published online: 12 August 2008

(C) The Author(s) 2008

\begin{abstract}
Most patients with mantle cell lymphoma present with a diffuse or nodular infiltration of the involved organs at diagnosis. We present two patients with a rare morphological variant, displaying a partial involvement of the mantle zone. Patient 1 presented with an enlarged inguinal lymph node, which showed marked follicular hyperplasia with singly spread Cyclin D1+ small lymphoid cells in the mantle zones. An additional lymph node biopsy taken 3 months later showed the same pattern. Patient 2 presented with a classical mantle cell lymphoma with lymph node, bone marrow and gastro-intestinal involvement. However, revision of an appendectomy specimen taken 4 years earlier showed pronounced follicular hyperplasia with singly spread Cyclin D1+ small lymphoid cells in the mantle zones. Mantle cell lymphoma with partial involvement of the mantle zone has rarely been reported and many represent an early manifestation of mantle cell lymphoma. Our cases also illustrate that the inclusion of an anti-cyclin D1 antibody in the diagnostic panel of antibodies to study unexplained follicular hyperplasia, might be advised.
\end{abstract}

Keywords Mantle cell · Lymphoma ·In situ" Variant

\footnotetext{
A. Bassarova $(\bowtie) \cdot$ A. Tierens $\cdot$ J. Delabie

Pathology Clinic, The National Hospital-

The Norwegian Radium Hospital,

Montebello,

0310 Oslo, Norway

e-mail: assia.bassarova@rr-research.no

G. F. Lauritzsen • A. Fosså

Department of Oncology, The National Hospital-

The Norwegian Radium Hospital,

Montebello,

0310 Oslo, Norway
}

\section{Introduction}

Mantle cell lymphoma comprises approximately 3-10\% of non-Hodgkin lymphomas. Most patients present with stage III or stage IV disease, and in at least $25 \%$ of the cases peripheral blood involvement is also found [5]. Gastrointestinal tract, bone marrow and Waldeyer's ring are the most commonly involved extranodal sites. Mantle cell lymphoma is characterized by a variable clinical course with a median survival of 3-5 years [5]. Prognosis is tightly correlated with lymphoma cell proliferation $[1,2,5]$.

Classical mantle cell lymphoma is characterized by a diffuse, nodular or mantle zone growth pattern. The lymphoma cells are small- to medium-sized with slightly to markedly irregular nuclear contours, moderately dispersed chromatin but inconspicuous nucleoli [1]. Immunophenotypically, mantle cell lymphoma is characterized by the expression of CD5 and cyclin D1. Cyclin D1 overexpression is due to a recurrent cytogenetic abnormality, $\mathrm{t}$ $(11 ; 14)(\mathrm{q} 13 ; \mathrm{q} 32)$ involving CCND1 and immunoglobulin heavy chain genes [9].

Recently, some cases of mantle cell lymphoma with a peculiar "in situ" growth pattern and apparent indolent clinical course have been reported [4, 6, 7]. Microscopic examination in all cases revealed follicular hyperplasia. The germinal centres were conspicuous and surrounded by an apparently normal or mildly expanded mantle zone. However, immunostaining for cyclin D1 revealed singly spread positive small lymphoma cells in the mantle zones $[4,6,7]$. In two of the reported cases, peripheral blood and bone marrow were also involved $[4,6]$.

In this paper we present two additional patients with a similar variant of mantle cell lymphoma. 


\section{Clinical history}

\section{Patient 1}

The 42-year-old female patient had noted a slowly growing mass in the groin. On physical examination a moderately enlarged lymph node was detected. Computer tomography and PET-CT further revealed moderately enlarged cervical, axillar, iliacal and inguinal lymph nodes with increased fluorodeoxyglucose (FDG) uptake. All relevant blood tests, including complete blood counts and LDH were normal. Further staging procedures including GI tract endoscopic biopsies and bone marrow trephine biopsy ultimately revealed Ann Arbor stage IVA lymphoma. Treatment was initiated according to the Nordic Mantle Cell Lymphoma III protocol, i.e. high-dose chemotherapy and retuximab with stem cell rescue; see http://www. Nordic-lymphoma.org.

\section{Patient 2}

A 65-year-old male patient presented with a 6-month history of mild coughing and moderately enlarged cervical lymph nodes. PET-CT revealed generalized lymph node involvement. Complete blood counts and other relevant blood tests, including LDH were normal. Surgical lymph node biopsy, endoscopic stomach biopsy and bone marrow biopsy showed Ann Arbor stage IVA lymphoma. The patient was also treated according to the Nordic Mantle Cell Lymphoma III protocol, i.e. high-dose chemotherapy and retuximab with stem cell rescue; see http://www. Nordiclymphoma.org. Four years earlier, the patient underwent appendectomy for acute appendicitis. At that time, no clinical suspicion for lymphoma was reported.

\section{Materials and methods}

Immunohistochemistry The paraffin blocks were cut at 4 $6 \mu \mathrm{m}$, dried overnight at $60^{\circ} \mathrm{C}$ and dewaxed in xylene. A standard panel with the following primary antibodies was used in both cases: CD20, CD10, BCL-6, BCL-2, CD3, CD5, CD21, CyclinD1, IgM and IgD. Heat-induced epitope retrieval was used for all stainings. Visualization was performed using the EnVision ${ }^{\circledR}$ method (DakoCytomation, Glostrup, Denmark) according to the manufacturer's instructions. Appropriate positive and negative controls were used.

Flow cytometry A four-color flow cytometric analysis was performed on whole bone marrow specimens, anticoagulated with heparin. Fifty microliters of whole bone marrow containing between 0.5 and $1 \times 10^{6}$ cells were stained for surface antigens with the following antibody combinations: fluorescein isothyocyanate (FITC)/peridininchlorophyll cyanine 5.5 (PercPCY5.5)/allophycocyanine (APC)-(1) CD20/CD5/CD19/CD43; (2) FMC7/CD23/CD19/CD5; (3) Simultest $\kappa / \lambda / C D 20 / C D 19$. Flow cytometry analysis was performed on a Facscalibur, using Cell Quest Pro software.

FISH analysis Fluorescent in situ hybridization (FISH) analysis was performed on formalin-fixed tissue specimens, using LSI IGH/CCND1 dual fusion DNA probe (Vysis, Downers Grove, IL, USA). The slides were deparaffinized, immersed in citric buffer for $60 \mathrm{~min}$ at $80^{\circ} \mathrm{C}$, followed by pepsin pretreatment and dehydrated in ethanol. After denaturation step for $5 \mathrm{~min}$ at $73^{\circ} \mathrm{C}$, hybridization was performed at $37^{\circ} \mathrm{C}$ overnight. The next day the slides were washed in sodium chloride-sodium citrate (SSC) buffer, counterstained with DAPI and evaluated using an Olympus BX61 microscope.

PCR analysis DNA was extracted from both fresh snap frozen and FFPE tissue using BioRobot M48 (Qiagen, Hilden, Germany). The quantity and quality of the extracted DNA were then checked and DNA was used for polymerase chain reaction (PCR) analysis of $\mathrm{Ig}$ heavy chain $(\mathrm{IgH})$. BIOMED-2-based PCR protocol and three sets of $\mathrm{VH}$ primers corresponding to the three VH FR regions (FR1, FR2 and FR3) were used [8]. The results were analysed using ABI Prism ${ }^{\circledR} 3100$ Genetic analyser.

Cytogenetics Fresh tissue samples were manually minced and enzymatically treated until a suitable suspension of cells and cell clumps was obtained. After 5-7 days culturing colchicines was added for the last $4 \mathrm{~h}$ and the short-term cultures were harvested according to standard protocols. The chromosomes in the dividing cells were then G-banded and a karyotype established in accordance with the recommendations of the International System for Human Cytogenetic Nomenclature.

\section{Results}

Patient 1

Axillary and inguinal lymph node biopsies were performed and showed the same picture. The overall architecture was preserved, with intact sinuses, B- and T-zones. Prominent follicular hyperplasia was noted with hyperplastic germinal centres and mantle zones. Because of the clinical suspicion of lymphoma, an extended investigation with a panel of antibodies for immunohistochemistry was performed. Surprisingly, anti Cyclin D1 immunostaining showed a rim of 
Fig. 1 Patient 1: a Lymph node biopsy with prominent follicular hyperplasia $(\mathrm{H} \& \mathrm{E}, \times 20)$.

b Cyclin D1 staining showing a rim of positive cells in the mantle zones $(\times 20)$. c Cyclin D1 staining showing a rim of positive cells in the mantle zones $(\times 100)$. d PCR results from inguinal lymph node and from axillary lymph node showing the same monoclonal immunoglobulin heavy chain gene rearrangement in a polyclonal background



positive cells in the mantle zones (Fig. 1). PCR analysis was performed on two consecutive biopsies using snap frozen and formalin-fixed tissue and demonstrated the same monoclonal immunoglobulin heavy chain gene rearrangement (Fig. 1). FISH analysis revealed spread single cells with $\mathrm{t}(11 ; 14)(\mathrm{q} 13$; q32.3) translocation. Cytogenetic analysis of the lymph node showed normal karyotype, 46, XX. The bone marrow biopsy showed a normal histology, CyclinD1 staining was negative, but flow cytometric analysis of bone marrow aspirate identified minimal (1\%) mantle cell lymphoma infiltration. Minimal involvement by lymphoma was also observed in the endoscopic biopsies from the stomach.

\section{Patient 2}

Cervical lymph node biopsy showed mantle cell lymphoma with mixed nodular and diffuse growth pattern. Cytogenetic analysis of the lymph node demonstrated an abnormal karyotype: 46, XY, t(11;14)(q13;q32). Endoscopic biopsies from the stomach and duodenum revealed minimal infiltration. Bone marrow trephine and flow cytometry showed bone marrow involvement. The pattern of infiltration in the bone marrow was diffuse, interstitial and intrasinusoidal with approximately $10-12 \%$ atypical lymphocytes (Fig. 2). The immunophenotype of the lymphoma was: CD5+, CD23-, CD19+, CD20+, CD79B+, immunoglobulin light chain kappa + , cyclin $\mathrm{D} 1+$.

A reexamination of the appendectomy specimen removed 4 years earlier revealed acute appendicitis with marked lymphoid hyperplasia. Many secondary lymphoid follicles with expanded mantle zones were noted in submucosa. Cyclin D1 staining revealed accentuated, expanded mantle zones in some follicles and small groups of positive cells in other areas (Fig. 2). FISH analysis revealed spread single cells with $\mathrm{t}(11 ; 14)(\mathrm{q} 13 ; \mathrm{q} 32.3)$ translocation (Fig. 2).

\section{Discussion}

Four cases of mantle cell lymphoma with an unusual morphology and indolent clinical course have recently been described $[4,6,7]$. A common feature of those cases was the 


4Fig. 2 Patient 2: a Appendix biopsy showing marked lymphoid hyperplasia $(H \& E, \times 20)$. b Cyclin D1 staining of the appendix revealed accentuated, expanded mantle zones in some follicles and small groups of positive cells in other areas $(\times 20)$. c Cyclin D1 staining showing a rim of positive cells in the mantle zones $(\times 100)$. d FISH analysis of the appendix showing single nuclei with one or two fusion signals and single red (native CCND1) and single green (native $\mathrm{IgH}$ ) signals (arrows) $(\times 600)$. e Lymph node biopsy showed mantle cell lymphoma with mixed-nodular and diffuse growth pattern $(\mathrm{H} \& \mathrm{E}, \times 20)$. $\mathbf{f}$ Cyclin D1 staining of the lymph node $(\times 20)$

pronounced follicular hyperplasia with reactive germinal centres and normal or mildly expanded mantle zones. Cyclin D1 staining revealed singly spread or a thin rim of positive neoplastic cells in the mantle zones. Based on the unusual histological picture Richard et al. introduced the term 'in situ-like' mantle cell lymphoma [7], in parallel with the in situ variant of follicular lymphoma [3]. The cases presented here show the same morphological characteristics. In one of the patients two consecutive lymph node biopsies showed marked follicular hyperplasia with single cyclin D1 positive lymphoid cells in the mantle zones. The second patient presented with classical mantle cell lymphoma, but reexamination of an appendectomy specimen removed 4 years earlier demonstrated cyclin D1 positive cells in the mantle zones of the follicles present in the wall of the appendix. At the time of the appendectomy, there were no clinical signs of lymphoma. Whether the minimal lymphoma localization in the appendix with concurrent follicular hyperplasia may have contributed to the acute inflammation, is a matter of speculation. At clinical presentation with lymphoma, both of our patients were diagnosed with Ann Arbor stage IVA disease based on the involvement of multiple lymph nodes, gastrointestinal tract and bone marrow. In two of the reported cases peripheral blood and bone marrow involvement was noted [4, 6] while in the two other patients only nodal disease was documented [7].

Histological examination alone does not raise suspicion of mantle cell lymphoma in the two cases of 'in situ' mantle cell lymphoma reported here. Only cyclinD1 staining can reveal this diagnosis. In view of the fact that these cases closely resemble reactive follicular hyperplasia on histologic examination, we suggest that cyclin D1 staining should be added to the analysis of unexplained follicular hyperplasia, either when occurring in elderly patients or when there is genuine clinical suspicion for lymphoma as in one of our patients. Whether the pattern of mantle cell lymphoma involvement presented here represents an early manifestation of mantle cell lymphoma, meriting the use of the term "in situ" mantle cell lymphoma, as previously defined, remains to be confirmed. However, the biopsy samples in our patient 2 , showing first partial involvement of the mantle zone in the appendix, and then massive mantle cell lymphoma in the lymph node 4 years later, is consistent with this interpretation.

Conflict of interest statement We declare that we have no conflict of interest.

Open Access This article is distributed under the terms of the Creative Commons Attribution Noncommercial License which permits any noncommercial use, distribution, and reproduction in any medium, provided the original author(s) and source are credited.

\section{References}

1. Argatoff LH, Connors JM, Klasa RJ, Horsman DE, Gascoyne RD (1997) Mantle cell lymphoma: a clinicopathologic study of 80 cases. Blood 89:2067-2078

2. Bosch F, López-Guillermo A, Campo E, Ribera JM, Conde E, Piris MA, Vallespí T, Woessner S, Montserrat E (1998) Mantle cell lymphoma: presenting features, response to therapy, and prognostic factors. Cancer 82:567-575

3. Cong P, Raffeld M, Teruya-Feldstein J, Sorbara L, Pittaluga S, Jaffe ES (2002) In situ localization of follicular lymphoma: description and analysis by laser capture microdissection. Blood 99:3376-3382

4. Espinet B, Sole F, Pedro C, Garcia M, Bellosillo B, Salidoa M, Florensa L, Camacho F, Baro T, Lloreta J, Serrano S (2005) Clonal proliferation of cyclin D1-positive mantle lymphocytes in an asymptomatic patient: an early-stage event in the development or an indolent form of a mantle cell lymphoma? Hum Pathol 36:1232-1237

5. Jaffe ES, Harris NL, Stein H, Vardiman JW ((ed)] (2001) World Health Organization Classification of Tumors. Tumours of Haematopoietic and Lymphoid Tissues. Lyon: IARC Press, pp 168-170

6. Nodit L, Bahler DW, Jacobs SA, Locker J, Swerdlow SH (2003) Indolent mantle cell lymphoma with nodal involvement and mutated immunoglobulin heavy chain genes. Hum Pathol 34:1030-1034

7. Richard P, Vassallo J, Valmary S, Missoury R, Delsol G, Brousset P (2006) "In situ-like" mantle cell lymphoma: a report of two cases. J Clin Pathol 59:995-996

8. van Dongen JJ, Langerak AW, Brüggemann M, Evans PA, Hummel M, Lavender FL, Delabesse E, Davi F, Schuuring E, García-Sanz R, van Krieken JH, Droese J, González D, Bastard C, White HE, Spaargaren M, González M, Parreira A, Smith JL, Morgan GJ, Kneba M, Macintyre EA (2003) Design and standardization of PCR primers and protocols for detection of clonal immunoglobulin and T-cell receptor gene recombinations in suspect lymphoproliferations: report of the BIOMED-2 Concerted Action BMH4CT98-3936. Leukemia 17:2257-2317

9. Williams ME, Swerdlow SH, Meeker TC (1993) Chromosome $\mathrm{t}(11 ; 14)(\mathrm{q} 13 ; \mathrm{q} 32)$ breakpoints in centrocytic lymphoma are highly localized at the bcl-1 major translocation cluster. Leukemia $7: 1437-1440$ 